\title{
Crosscurrent
}

\section{Broken promises of Internet and democracy: Internet art in Serbia, 1996-2014}

\section{Nina Mihaljinac}

University of Arts in Belgrade, Serbia

\section{Vera Mevorah}

Independent Researcher, Serbia

\begin{abstract}
The article uses case studies of artistic and cultural practices on Internet in Serbia (1996-2014) to provide a deeper analysis of possible uses of internet technology and internet art for social and political change as well as showcasing changing attitudes toward the internet in a transitional semi-periphery state. Through analyzing these questions, the article defines several phases of development of internet and art projects in Serbia including (a) the phase of techno-utopia when internet technology was used for staging and supporting student protests and the so-called first 'internet revolution' in Serbia (1996-1999); (b) the phase of ambivalence or 'mixed feelings' toward the Internet, triggered of by Kosovo War and North Atlantic Treaty Organization (NATO)-led bombing of 1999-2000; (c) the phase of optimism and hope about the Internet after the 'October 5th' revolution (2000-cc. 2005); and (d) the phase of disillusionment with both the Internet and democracy (2010-2014). This study re-evaluates early achievements and democratic principles of networked society and illuminates core issues and accomplishments of cyberculture from the 1990s until present times through the point of view of multiple actors present within Serbian art and culture.
\end{abstract}

\section{Keywords}

activism, art, democracy, internet, NATO bombing, Serbia

\section{Introduction}

Possibilities for social engagement and creative aspects of internet technology attracted cultural and art circles around the Western world throughout the 1990s and 2000s. This creative flux (Bazzichelli, 2006; Greene, 2004; Lovejoy, 2004; Lovink, 2002, 2009; Stallabrass, 2003) is particularly interesting to observe 
in the context of Serbia, since a significant amount of internet activist art practices 1 coincided with Serbia's political transition to democracy and political events leading to this transition period (citizen protests (1996-1997) during the international sanctions and Slobodan Milosevic totalitarian regime; Kosovo War (1998-1999) and North Atlantic Treaty Organization (NATO) bombing, 1999; and post-Milosevic democratic changes and abolition of sanctions, 2000). In this article, the relations between the Internet 2 and art/cultural production are analyzed within the context of Serbia's political and social environment. Starting from the basic postulates of critical theory, we set off with the definition of artworks as discourses and political texts. Thus, the analysis illuminates the transformation of the close relationship between politics, art, new technologies, and digital production in Serbia in the context of Serbia's newly introduced democracy. The particular aim is to stress the reasons why the Internet as well as political events had a significant impact on a whole period of art practice in Serbia from 1996 until the middle of the 2000 s.

The research includes case studies (artworks, online networks, and projects) from 1996 until beginning of the second decade of the 21st century. The period of the NATO bombing represents a culmination and overlapping of the artistic, political, and media (internet) activism in Serbia, when art practices first sowed seeds of doubt about the Internet as a free and truly democratic medium. This skepticism can be related to Virillio's (1995) thesis about totalitarianism being latent in technology, although certainly, as the study will show, for many artists, the Internet meant something quite different - a means of establishing dialogue and peace.

In order to best show how the internet and new media technologies affected artists and activists in Serbia during this period, case studies are categorized as follows: (a) Serbian participation in Nettime and Syndicate mailing lists, which first enabled online international communication in Serbia under sanctions; this was the period of the first commercial internet access, the emergence of Internet art, and civil society activism, coinciding with the student protests of 1996-1997 and the so-called first internet revolution (Bennahum, 1997); (b) Reality Check, Period After, Target, Art rat, Andrej Tisma, Warframes internet, and art/culture practices during the NATO bombing of Yugoslavia - which was proclaimed the first internet war (Bieber, 2000; Keenan, 2001; Matheson and Allan, 2009); and (c) Kuda.org online and offline activism in the post-Milosevic democratic period in the 21st century. These case studies provide a local contribution to the fields of Internet studies, theory of new media, and information. Through the lens of art history and cultural policy in Serbia, we analyze the role of internet art practice in conceptualizing an information society (Greene, 2004; Stallabras, 2003) and in 
providing a platform for rethinking contemporary digital culture, both in Serbia and on a global level.

\section{Internet (art) revolution in Serbia, I996-1997}

The official reason for the international sanctions of Serbia, which intermittently lasted from 1992 to 2000, was the inclusion of the state under the command of Serbian President Slobodan Milosevic into the war in Bosnia during the breakup of the Socialist Federal Republic of Yugoslavia (SFRY). From the beginning of the conflict, a vast number of Serbian citizens were against both the war and Milosevic's regime, which provoked a lot of dissatisfaction in the country. The first wave of street protests was organized during the breakup of the SFRY in 1991-1992 and the second in 1996. Starting from this year, which coincides with the beginning of commercial use of internet technology, the internet proved to be the best tool for fast and censorship-free communication between protesters. It was in this context that term internet revolution $n$ was first coined. David Bennahum (1997) from Wired magazine wrote, 'The student protests are producing data on whether expanded access to information is utterly inconsistent with authoritarian government [...]'. Throughout the second half of the 1990s, Serbian nongovernmental organizations (NGOs), political activists, and artists opposing Milosevic gradually joined the worldwide enthusiasm for the possibilities of the Internet and new communication technologies. This process was mainly supported by international actors; as Milena Dragićević-Šešić (2011) states, 'an alternative cultural scene assisted by national Soros foundations, accessed the free cyberspace long before state cultural institutions and art academies' (p. 59). Therefore, digital culture in Serbia developed in the spirit of political and cultural activism and the struggle for democracy.

Communities in Europe and the United States also had a desire for collaboration and communication across borders, not as a consequence of seclusion, as it was the case in Serbia, but rather driven by the new and exciting possibilities of internet technology. Ideological platforms of these newly formed networks were closely tied to the promise of an open and democratic world that came after the fall of the Berlin wall in 1989 and were strengthened further with the (techno)utopic views of the Internet in the early 1990s. While projects like The WELL and The Thing were true pioneers of online communication, it was not until virtual communities like Nettime and Syndicate that art networks truly became international in their scope and an equitable playing field was available for all. The history of the Nettime and Syndicate respective communities and the experiences of Serbian citizens in them provide a significant context for understanding both hopes and illusions about early digital culture in Serbia and throughout the world. 


\section{Nettime and Syndicate - Serbia and networked society}

The mailing list Nettime was founded in 1995 and Syndicate a year later. Both networks were launched with the idea of gathering cultural professionals and Information Technology (IT) enthusiasts in a discussion of possibilities of the Internet, for art, culture, and society. Subjects of copyright, privacy, artificial intelligence (AI), e-commerce, internet democracy, and digital obsolescence were discussed in detail. These communities saw in the new communication medium opportunities for further development of a global society and at the same time a new arena for artistic exploration.

Nettime was a collaborative think tank, a space where people like Lev Manovich, McKenzie Wark, and Bruce Sterling discussed the digital world, where ideas of non-hierarchical organization, learning, and production were pushed to the limit. Significant contribution came from net artists (Vuk Cosic, JODI, Alexei Shulgin, and others) through their experimentations with the norms of online communication and the role of art in a networked society.

While Nettime was mostly a place of discussion along the lines of US technoutopianism and European techno-skepticism, the Syndicate was conceived with a specific task of supporting the V2_East project of bridging the divide between Western and Eastern European cultural workers and imagining and creating together a new European landscape - Deep Europe. For Syndicate members devoted to this goal, Deep Europe meant a continuation of the critical exploration of what post-1989 Europe is and could be, as well as questioning the position of East Europeans in this West-dominated geopolitical sphere. Until its transformation into the new network SPECTRE in 2001, Syndicate included over 500 individuals in over 30 countries, while Nettime counted 3000 by 2002.

Considering that Yugoslavia was under sanctions from 1996, for Serbian citizens, the mailing lists represented an open window into the world, a space where they felt they could be equal contributors, with equity in public discourse, and where local issues truly seemed part of a larger picture. Drazen Pantic, a mathematics professor from the University of Belgrade, introduced the first free internet project in Serbia - Opennet on Nettime in 1995 and continued discussing radio B92's ${ }^{3}$ practice and situation in Serbia throughout the 1990s. Literary theorist Novica Milic was the first to report on the student protests against the Milosevic government in December 1996. Novi Sad artist Andrej Tisma started participating in 1997 and was soon joined by artists Aleksandar and Branka Davic and hacker and activist Vesna Manojlovic. In 1998, Sinisa Rogic announced the birth of Cyber Rex - first media lab in Belgrade. 
The role of the Serbian art community in these networks was in no small part documented by one of Nettime's founder Geert Lovink (2002, 2009), but it was the issue of the Kosovo War and the NATO bombing of Yugoslavia in 1998 and 1999 that produced the highest traffic on both Nettime and Syndicate. Daily news was forwarded, and polemics could be heard from both anti- and pro-war sides. Regular reports on both networks came from Slobodan Markovic and B92 editorial staff, as well as from Branka Curcic, Andrej Tisma, and Dejan Sretenovic. The question of Kosovo was considered an important part of the Deep Europe concept and proved to be the tipping point for internet communities (Lovink, 2009: 129). The first couple of years of Nettimeand Syndicate truly marked a period of excitement and optimism about possibilities of the Internet. However, the hope of breaking old stigmas and legacy of North/South and West/East divides never disappeared thanks to some very old and very physical issues.

\section{Internet as radical media - Kosovo War and NATO bombing of Serbia}

The citizens' protests in Yugoslavia failed to overthrow Milosevic. In 1998, he was accused by the international community of carrying out ethnic cleansing of Kosovo's Albanians, which resulted in the initiation of the NATO bombing of Yugoslavia in 1999. The intervention was carried out without the approval of the United Nations Security Council. This controversial event marked the end of the SFRY civil wars and represented the last phase of Milosevic's totalitarian regime. Only after the bombing, Milosevic lost the elections in 2000, and a democratic coalition won the government. This was followed by democratic changes, abolition of sanctions, and internationalization. The NATO bombing of Yugoslavia was also a globally significant phenomenon because it represented one of the first global military interventions and the first internet virtual war (Chapman, 2008; Ignatieff, 2000; Virillio, 2000).

The Internet has also influenced the change in concepts and content of artworks, as well as the restructuring of the artistic field in the country. Among various artistic practices and positions, two opposing groups of artists emerged: those 'activist' who were fascinated by the new media and those 'escapist' who refused to use it, insisting on preserving traditional values - both in terms of politics/ideology and art practice. The official art scene was trying to preserve traditional values by choosing 'nationalistic or escapist discourse - discourse of oblivion, while the independent art scene was trying to make certain steps toward socially relevant, "artivistic art" (Dragićević Šešić, 2013). Those activist initiatives were mostly supported from abroad (e.g. The Center for Contemporary Art in Belgrade used the server of the Budapest New Media Center C3). Precisely, because of the need to establish dialogue and because of the promise of a 
democratization of the public sphere, the activist art scene produced largest number of internet artworks.

Reality Check and Stop the violence! (Period After) - peace and communication

The dominant idea of internet art projects during the bombing was to open a dialogue and establish a testimonial alliance (Hartman, 2006: 438) on the international level. Reality Check, the first internet art project in Serbia during the bombing was initiated by two curators Dejan Sretenovic and Darka Radosavljevic within the Center for contemporary Art. The goal of their project was to present contemporary internet art production in Yugoslavia; using the web for the dissemination of works; to review, reconsider, 'check' on the reality of the situation in the country; and to share with the international community (Reality Check, 1999).

Through curatorial interventions and a series of subjective artistic realities, the project provided a common framework for interpretation of the bombing and constructed a new, objective narrative of Yugoslavia in 1999. The first part of the project was an internet platform realitycheck.c3.hu, presenting artist biographies and their works, including Era Milivojevic, Rasa Todosijevic, Milica Tomic, and Uros Djuric. The second part was the production of 18 postcards which served as a medium for establishing broken links and communication with foreign countries. As a form of communication, postcards provided security during a time of general mistrust in the effectiveness of the internet. Topics of individual artworks within Reality Check came mainly from the field of geopolitics: policy of sanctions, Cold War, critique of capitalism, religious conflicts, postcolonial criticism and orientalism, EU politics, women in war, and control and surveillance.

It wasn't only Serbian professionals who felt the need to express their experiences during the bombing. The international community also showed initiative to communicate and re-examine their position within the conflict. Expressing the fear that 'every new day of the war will damage European cultural self-understanding and understanding of its fundamental assumptions' (Pruscha, 1999), a group of professors from the Academy of Fine Arts in Vienna, among them Carl Pruscha, Michael Benedikt, Gerhard Botz, Gerda Buxbaum, and Leopold Specht, decided to make a public request 'to immediately stop the expulsion of the Albanian population from Kosovo, to unconditionally cease all aspects of the war and to start peace agreements at the UN level' (Pruscha, 1999). Public request, in a form of a participatory activist project Stop the violence, was realized in cooperation with the Austrian Museum of Contemporary Art and the Faculty of Fine Arts in Belgrade, containing texts and posters created by artists 
coming from Albania, Yugoslavia, Macedonia, Austria, Scandinavia, United States, Australia, and so on. The poster artworks brought a diversity of narratives of the bombing: accusation and irony of primitivism and the 'ease of killing', announcements of the apocalypse, direct anti-war agitations, and pacifist messages with universal symbols of peace. One of the key points of the project was the effort to advocate for the protection of human rights endangered by the false rhetoric of 'humanitarian war' and its deadly outcomes. The exhibition was held in the capitals Vienna, Belgrade, Tirana, Sarajevo, Budapest, and Berlin, with various accompanying programs, such as public debates, presentations, and other forms of dialogue on the subject of the bombing. In order to establish a more dynamic dialogue with the international audience, an online database was launched on the internet platform of Period After. This platform was built by the Austrian organization Public Netbase t0 in 1999 to open a public media space for the free dialogue of citizens and intellectuals from all over the Balkan region who were interested in analyzing the sociopolitical, cultural, and media space in Yugoslavia during the war.

\section{Target, Art rat, and Andrej Tisma - Internet wars}

Aside from projects aimed at promoting peace and reconciliation, a number of art projects used the internet quite differently - as 'weapons of war'. The closest link between artistic and political anti-war activism is showcased by the Target project, created by an anonymous group of artists from Serbia.

Target graphics was one of the most striking symbols of the bombardment and was printed on badges, posters, and other materials used in public protests against bombing, first in Serbia and then throughout the world. Creative variations of the digital display of a target 'were digitally smuggled' (Vallen, 2007) over the Internet so that activists 'on the other side of the screen' could print the downloaded images as protest banners. The symbol was first used for Serbian and global anti-war campaign against the NATO bombing of Yugoslavia and later against other interventions. In this way, according to Vallen, '[...] Kosovo conflict became the first internet war, with all sides disseminating information and propaganda through e-mails and web sites' (Vallen, 2007). Target served as a critical review and deconstruction of the meaning of the euphemistic military terms 'target' and 'collateral victim' (Mihaljinac, 2017: 182), with an aim to show that the real targets of the NATO bombs were actually the vulnerable bodies of civilians.

A similar methodology of internet activism was used in Art rat (Art War) project by Branislav Knezevic and Dorijan Kolundzija. The first phase consisted of 
a series of joint student-professor exhibitions from the Faculty of Applied Arts in Belgrade at the Gallery of the Cultural Center Belgrade and the independent gallery $12+$. The second phase moved the project online, to use Vallen's terminology, Art War images 'were digitally smuggled' (Vallen, 2007) from Yugoslavia to the United States and exhibited at the Peace Action Center in Milwaukee, Wisconsin. In accordance with the principles of internet as a democratic medium, the project was conceived as a participatory process for creating a 'nucleus of the future bank of artistic antiwar ideas of potential users' (Feries et al., 2001) and consisted of anti-war posters by young Serbian artists Dorijan Kolundzija, Dusanka Komnenic, Sasa Bradic, Viktor Mijatovic, Ivana Radosavljevic, and Slavisa Savic. Posters created for the project criticized neoliberal capitalism, tying it to US politics and pointing to the cessation and dramatic consequences of its actions - killing and death.

The practice of Novi Sad contemporary artist Andrej Tisma is another example of using the internet as an 'artistic weapon'. During the bombing, Tisma produced two websites: one where he responded to questions from around the world about the bombing and another created as a duplicate - an artistic copy, takeover of the KFOR (Kosovo Force operated by NATO) website, which he used to report on the Kosovo War. The website plagiarism subverted KFOR's rhetoric through the articles written by Tisma, completely disputing KFOR's original reports. Tisma also produced a number of texts (online bombing diary How to survive $a$ bombing illustrated by private and documentary photos) and net artworks in 1999, like Bomb Contest, Eyewitness to the Bombing, NATO Olympic Mascots, and so on. His activity on Nettime and the Syndicatewas an internet war in itself. For his criticism directed against NATO, and what he believed was the moderator's 'Soros politics', he was denied access to the list on several occasions. The first message on the topic of the NATO bombing which appeared on Nettime was from Andrej Tisma and said, 'Message from Serbia, in anticipation of the NATO bombing. It could be my last post. But do not worry. If I die, my website will remain' (Lovink, 2009: 132).

\section{Warframes - questioning the Internet}

Artists and intellectuals were 'aware of the fact that today most important media transmitted memory, regardless of whether it has been individually processed, constructed or collectively lived, gets quality, objectivity and truthfulness from the media' (Hoskins, 2009: 27). Thus, some of them were skeptical both about the internet as a truly free new media and about the bombing as a humanitarian intervention. This suspicion was amplified by the fact that both could be seen as 
emblems of a new global technocratic society, a society of spectacle, surveillance, and control.

In this regard, one of the most complex strategies of representation of the bombing found in internet artworks was a strategy of simultaneous use and critical reflection of the new media as a symbol of new democracy. One example of such a meta-work is Warframes by Zoran Naskovski, created within the Reality Check project (but Naskovski later separated from the group). This is the most internationally exhibited and recognized artwork about the NATO bombing (Carnival in the Eye of the Storm - War/Art/New Technologies: KOSOV@, Portland, SAD; Always Already Apocalypse, 1999, Istanbul, Turkey; the Venice biennale in 2007, international selection, at the invitation of Robert Storr, curator of the biennale and of the New York Museum of Modern Art (MOMA)).

Warframes is an internet archive of video frames taken from the television program which was broadcasted during the bombing on local TV stations (e.g. news frames, war images, frames of political programs, official speeches, movies, commercials, etc.). This artwork is '[...] a radical expression of using television programs as ready-made images in exceptional circumstances' (Milevska, 2002: 190). The title of the artwork, Warframes, relates not only to the mechanism of media construction of war images which are framed on the screen but also to the more complex and less visible system of sociopolitical frames which construct those war images. The polysemy of the title is reflected in the selection of television frames that interpret the phenomenon of media, primarily television (frames that show first television sets and first TV commercials), and of frames that are examining political and economic circumstances that led to the bombing. (e.g. frames that show meetings of American, European, and Serbian officials). (Mihaljinac, 2017: 191).

The artwork criticizes neo-capitalist consumer society and the society of spectacle and mass media as their primary weapon. Whatever the ideology they represent, the media use the same techniques of representation of desired truths. The main target of criticism in Warframes is the binary opposition constructed in media discourse: the good and the bad and criminals and victims. In other words, every media-mediated image of the world is defined by some ideology and political interests. Therefore, Warframes talks about the media (both television and the Internet) as instances of power and tools of manipulation, expressing a radical doubt about the concept of media freedom.

\section{Breaking the (techno)utopic promise - Internet and art in Serbia in the 2 I st century}


The first elected democratic government in Serbia, in 2000, brought general enthusiasm both inside and outside the country. The event propelled capital, resources, and ideas to flow into the country to greet the new democracy and its role in networked society. Most NGOs, working groups, research, and strategies relating to the information and communications technology (ICT) were being

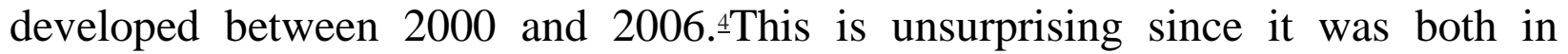
agreement with Serbia's proclaimed path toward becoming a member of the European Union as well as joining the global internet hype.

Several nodes, such as Cyber Rex, Remont gallery, and Kuda.org, provided a significant number of resources on citizen education and program development in this area. The newly connected art world was supported and nurtured outside the cyberspace, with regular meetings and workshops at Ars Electronica, Next 5 Minutes, and other festivals, through development of media laboratories like V2_East and Public Netbase t0. A long-held desire for reconciliation of differences within Europe, and particularly in ex-Yugoslavia, was reflected in newly established networks in the Balkans (A network project by MaMa in Zagreb, pro.ba/SCCA in Sarajevo, Ljudmila in Ljubljana, and Kuda.org in Novi Sad).

Early cyberscapes differ substantially from cyber and digital culture in Serbia, as in many other parts of the world, in the second decade of the new millennia. With the advent of Web 2.0, the number of internet users in Serbia grew steadily and their habits changed substantially. By 2014, most businesses had an online presence and almost half of the population used the internet for everyday news, commerce, and entertainment (Mevorah, 2015: 79-84). But despite the government's proclaimed interest in all things democratic, Serbia's ICT infrastructure developed slowly, with little progress. As the world slowly turned digital, critical thinking and questions about the Internet and the newly introduced democratic system have changed.

\section{Kuda.org - disillusionment and the present}

Inspired and supported by Austrian Public Netbase t0 laboratory, Kuda.org was formed as a artistic research laboratory in 2001 by Zoran Pantelic, Eduard Begovic $(\dagger)$, and P.RT collective (Vladimir Radisic and Jovan Trkulja), soon joined by Branka Curcic and Kristijan Lukic, focusing on cultural and educational production in information society. Their word kuda means 'where' in Serbian, paired with traditional non-profit domain '.org' reflected goals to question the direction or digital culture and Serbia's role in it. In the first few years of Kuda's existence, it was one of the main actors developing digital culture in Serbia. 
Kuda.org grew out of the contemporary art collective called Asocijacija Apsolutno. Zoran Pantelic, Dragan Miletic, Dragan Rakic $(\dagger)$, and Bojana Petric formed Apsolutnoin 1993 within a closed cultural environment of UN sanctions, following like many others at that time, critical and activist ideas of the Yugoslav Neo-avant-garde (see: Djurić and Šuvaković, 2003). Much of their work was formulated as a political response to the situation in the country, but always watchful of the world outside of Yugoslavia's borders. Throughout the 1990s, Apsolutno collective participated in a newly formed networked art communities, especially through the mailing list Syndicate and already developed media laboratories in Europe like Public Netbase t0, Ljudmila (Ljubljana Digital Media Lab), ZKM, and V2_East.

With over 50 workshops and lectures (2001-2006) and numerous published books on important digital issues, Kuda.org (at the time, one of the associations' Apsolutno initiatives) became an open educational space for discussing the newest practices and problems of the digital world. In their venue in Novi Sad, internet connection was freely available to citizens together with a rich library on issues of digital art and culture.

But, starting from 2007, Kuda.org's focus on the digital started to dwindle. Realizing that local issues were becoming focussed on public spaces, economy, and youth status, Kuda.org started to reconsider the impact and significance of internet technology and culture for Serbian society. For example, their project Lokalne politike $i$ urbana samouprava (Local Politics and Urban Selfgovernment) focused on informing the citizens on their rights together with roles and possibilities of local self-government. Although the project has an online platform, the majority of communication is achieved through weekly forums, conferences, lectures as well as through the printed newsletter Stanar (Tenant), edited by house council presidents and distributed in 20,000 copies.

Kuda's focus is no longer on the Internet. As Zoran Pantelic explains, the time when Kuda.org was oriented on technology-society and technology-art axes was a time of innovative practices in new media, primarily in the context of democratization of media promoted predominantly in art and hacker communities, which today denotes a completely different ecosystem [...]. (Mevorah, 2015: 213)

The generation of Serbia's digital natives didn't fully perceive networked society as a solution and promise of a better society. What is more is that information reality - which constitutes the everyday life of the average Serbian citizen in the past 5 years, especially for the younger generation - blended with the 
old issues of the offline world and took a backstage in cultural production countrywide.

\section{Conclusion}

To understand the Internet as a truly global and social phenomenon, it is paramount to revisit local digital histories and analyze specific contexts that produce common digital heritage. Art and cultural practices on the Web (online art communities, net art, multi-user projects, etc.), created also by Serbian citizens, played an important role in the information revolution. Changing attitudes toward the Internet and its possibilities, present around the world, in context of Serbia had strong political background and bring us important views on overlapping of politics, technology, and art in general. Furthermore, they strongly point to the significance of geopolitics on the development and utilization of internet technology.

In the beginning, the use of the internet in Serbia signified the battle against totalitarianism, the fight for democracy, as well as openness that Serbia lacked during UN sanctions. After becoming a democratic state and actively participating in networked society, many Serbian artists gave up on both promises of democratic system and the Internet as a democratic media source/platform and are trying to find new ways of building a democratic society.

Discussion about the Internet, culture, and art in Serbia opens significant questions about the future of networked society. Is the Internet, as Naskovski postulated, just like any other media - a tool of political propaganda and social discipline (Foucault, 1995) or is there really a window of freedom and potentiality for activism, transparency, and new forms of democracy? In a world where the digital becomes a vital part of everyday life, it's never been more important to raise the question about whether the Internet brings only the illusion of openness and democracy. Some consider that the battle for the free Internet is already lost (Mollen and Sunde, 2015); however, digital culture that inspired art and activist practices on the early web continues to live through movements such as WikiLeaks, Anonymous, and Bitcoin. Internet art practices in the 1990s and during the beginning of 2000s, both in Serbia and internationally, showed that there is a possibility for utilizing technology for social growth, transparency, international communication, and reconciliation. The question remains whether it is possible to use this potential and in what way.

\section{Funding}


The author(s) received no financial support for the research, authorship, and/or publication of this article.

\section{Notes}

I.Case studies analyzed in this article all utilize internet technology and culture and fall under several definitions of internet-based art practices: net art projects as defined by net.artpioneers Vuk Cosic, Alexei Shulgin, Olia Lialina, and others, meaning art or activist projects that use internet and web technology to create novel esthetic and conceptual frameworks (Sallabrass, 2003); internet platforms, defined by Olga Goriunova interactive online network projects which 'produce art' in some manner (Goriunova, 2012); and projects which enter into dialogue with different aspects of cyberculture both local and global.

2.Throughout this article, capital letter 'l' will be used when discussing the Internet as a specific, in a sense 'unified' global phenomena, stressing the interconnectedness and significance of its physical, technological, social, and ideological aspects and following the example of Internet Engineering Task Force (IETF), Internet Society, W3 and Internet Corporation for Assigned Names and Numbers (ICANN). Small letter 'i' will be used when addressing specific technological aspects or utilization of technology.

3.Radio B92 was the first and most important opposition media throughout the 1990s, and its broadcasting was often obstructed by Milosevic regime. See Antonela Riha, Serbia: How Radio B92 emerged and disappeared? (Riha, 20I5).

4.CePIT - Center for Information Technologies Research (Centar za proučavanje informacionih tehnologija), RNIDS - Serbian National Internet Domain Registry (Registar nacionalnog Internet domena Srbije), Center for Internet Development (Centar za razvoj Interneta), Internodium, and so on.

\section{References}

Bazzichelli T (2006) Networking: The Net as Artwork. Milan: Digital Aesthetics Research Center.

Bennahum SD (1997) The Internet revolution. Wired, 4 January. Available at: https://www.wired.com/1997/04/ff-belgrad/ (accessed 11 June 2013).

Bieber F (2000) Cyberwar or sideshow? The Internet and the Balkan Wars current history.

Proquest.

Available at: https://search.proquest.com/openview/4779876bc21221930395e2f9733eafd2 $\underline{11 \text { pq-origsite }=\text { gscholar\&cbl }=1816367}$

Chapman J (2008) War and Film. London: Reaktion Books. 
Djurić D and Šuvaković M (2003) Impossible Histories: Historical Avant-Gardes, Neo-Avant-Gardes, and Post-Avant-Gardes in Yugoslavia, 19181991. Cambridge, MA: The MIT Press.

Dragićević Šešić M (2011) Turning the power of art against fear and hatred. In: Sudetic CH (ed.) Building Open Society in Western Balkans. New York: Open Society Foundations. Available at: https://www.opensocietyfoundations.org/sites/default/files/open-societywestern-balkans-20111004.pdf (accessed 12 May 2017).

Dragićević Šešić M (2013) Politika sećanja i pravo na pobunu. Belgrade: Institute of Faculty of Dramatic arts, pp. 1-20. Available at: http://www.fdu.edu.rs/uploads/uploaded_files/_content_strane/2013_milena _dragicevic_sesic.pdf(accessed 12 May 2017).

Feries C, Kolundžija D and Komnenić Lj (2001) Art war. Afterimage. Available at: https://www.questia.com/library/journal/1G1-76560780/art-war (accessed 20 March 2013).

Goriunova O (2012) Art Platforms and Cultural Production on the Internet. New York: Routledge.

Greene R (2004) Internet Art. London: Thames \& Hudson.

Hartman G (2006) Shoah and Intellectual Witness. New York: Partisan Review. Available at: http://readingon.s3-website-us-east1.amazonaws.com/issue1/articles/Hartman/RO\%20-\%202006\%20\%20Hartman.pdf(accessed 13 June 2015).

Hoskins A (2009) The mediatization of memory. In: GardeHansen J, Hoskins A and Reading A (eds) Save $\quad$ As $\quad \ldots \quad$ Digital Memories. London: Palgrave Macmillan, pp. 27-44.

Ignatieff M (2000) Virtual War: Kosovo and beyond. New York: Picador.

Keenan T (2001) Looking like flames and falling like stars: Kosovo, 'the first Internet war'. Social Identities 7(4): 539-550.

Lovejoy M (2004) Digital Currents: Art in the Electronic Age. London: Routledge. Lovink G (2002) Dark Fiber: Tracking Critical Internet Culture. Cambridge, MA: The MIT Press.

Lovink G (2009) Dynamics of Critical Internet Culture (19942001). Amsterdam: Institute of Network Cultures.

Matheson D and Allan S (2009) Digital War Reporting. Cambridge: Polity Press. 
Mevorah V (2015) Internet i umetnost na prostoru Srbije 1996-2013 - Odlike umetničkih diskursa

na polju Interneta $u$ Srbiji. PhD Thesis. University of Arts in Belgrade, Serbia.

Mihaljinac N (2017) Svedočenje i reprezentacija traume u vizuelnim umetnostima: NATO bombardovanje Jugoslavije. Belgrade: University of Arts.

Milevska S (2002) Readymade and the question of fabrication of objects and subjects. In: Hoptman LJ and Pospiszyl T (eds) Primary Documents: A Sourcebook for Eastern and Central European Art Since the 1950s. New York; London: The Museum of Modern Art, The MIT Press, pp. 182-191.

Mollen J and Sunde P (2015) Pirate Bay founder: 'I have given up'. Motherboard. Available at: https://motherboard.vice.com/en_us/article/qkjpbd/pirate-bayfounder-peter-sunde-i-have-given-up (accessed 17 September 2016).

Pruscha C (1999) Preface, stop the violence!!! Period after. Available at: http://periodafter.t0.or.at/equi/layout01/lay01/c stop/c stop text 021.htm (a ccessed 13 April 2014).

Riha A (2015) Srbija: kako je nastao i nestao Radio B92. Osservatorio Balcanie Caucaso. Available at: https://www.balcanicaucaso.org/bhs/zone/Srbija/Srbijakako-je-nastao-i-nestao-Radio-B92-163188 (accessed 27 March 2015).

Stallabrass J (2003) Internet Art: The Online Clash of Culture and Commerce. London: Tate Publishing.

Vallen V (2007) Jasper Johns: Target with Body Parts. Mark Vallen's: Art for a change. Available at: http://art-for-a-change.com/blog/2007/02/jasper-johnstarget-with-body-parts.html (accessed 19 June 2014).

Virilio P (1995) Global Algorithm 1.7: The Silence of the Lambs: Paul Virilio in Conversation. C-Theory. Available at: https://journals.uvic.ca/index.php/ctheory/article/view/14317/5093 (accessed 19 June 2014).

Virillio P (2000) Strategy of Deception. New York: Verso Books. 